\title{
MENGEMBANGKAN SPORTIVITAS MELALUI PERMAINAN MODIFIKASI HOT (HOKI TIUP)
}

\author{
Vivi Sufiati \\ Universitas PGRI Madiun \\ Email: vivisufiati@unipma.ac.id \\ Dwinda Damayanti \\ Universitas PGRI Madiun \\ Email: dwindad64@gmail.com
}

\begin{abstract}
This study aims to determine the development of sportsmanship in children through a modified game of HOT (Hoki Tiup) during the pandemic. The research was conducted at Rumah Belajar All Kids. The research subjects were selected by purposive sampling, namely 4 children aged 5-6 years who did limited face-to-face learning. This research is a qualitative research with a case study approach. Methods of data collection used interviews, observation, and document study. The data analysis was used the data reduction stage, data presentation and conclusion drawing. The results of this study indicate that sportsmanship develops from the aspects of respect, fairness, and acceptance of the results of the game. Respect is shown through natural expressions when experiencing victory or defeat. A fair attitude is marked by the child starting to obey the rules of the game when playing with all his friends. The child receives the final result of the game.
\end{abstract}

Key words: Playing; hoki tiup; sportsmanship; pandemic covid-19

Abstrak: Penelitian ini bertujuan untuk mengetahui pengembangan sikap sportif dalam diri anak melalui permainan modifikasi HOT (Hoki Tiup) di masa pandemi. Penelitian di lakukan di Rumah Belajar All Kids. Subjek penelitian dipilih dengan purposive sampling, yaitu 4 anak usia 5-6 tahun yang melakukan pembelajaran tatap muka terbatas. Penelitian ini merupakan penelitian kualitatif dengan pendekatan studi kasus. Metode pengumpulan data menggunakan metode wawancara, observasi, dan studi dokumen. Analisis data yang digunakan adalah tahap reduksi data, penyajian data dan penarikan kesimpulan. Hasil penelitian ini menunjukkan bahwa sportivitas berkembang dari aspek menghormati, adil, dan menerima hasil permainan. Sikap menghormati ditunjukkan melalui ekspresi wajar ketika mengalami kemenangan maupun kekalahan. Sikap adil ditandai dengan anak mulai menaati aturan main ketika bermain dengan semua teman. Anak menerima hasil akhir dari permainan.

Kata kunci: Bermain; hoki tiup; sportif; pandemi covid 19

\section{PENDAHULUAN}

Indonesia termasuk negara yang mengalami dampak dari Covid19. Kebijakan PSBB maupun PPKM sudah pernah dilakukan untuk menekan percepatan virus. Masyarakat dihimbau untuk beraktivitas dirumah, mulai dari bekerja, belajar, dan beribadah. Hal ini dilakukan 
Vivi Sufiati, Dwinda Damayanti, Mengembangkan Sportivitas Melalui Permainan Modifikasi Hot (Hoki Tiup)

untuk mencegah penularan virus Covid-19. Adaptasi pelaksanaan pendidikan terjadi di semua jenjang. Anak usia dini juga melakukan adaptasi pembelajaran di rumah yang merupakan implementasi dari Surat Edaran Menteri Pendidikan Dan Kebudayaan No 4 Tahun 2020 tentang pelaksanaan pendidikan dalam masa darurat Corona Virus Disease (Covid-19). Orang tua memiliki kewajiban untuk mendampingi anak di rumah. Belajar untuk anak usia dini dilakukan dengan bermain. ${ }^{1}$ Mulyasa menyatakan bahwa bermain untuk anak usia dini merupakan kegiatan yang dapat digunakan untuk mempelajari banyak hal yang ada di sekitar, mengenal aturan yang berlaku, melakukan sosialisasi dengan masyarakat, menempatkan diri sesuai keadaan, mengontrol emosi diri, menanamkan sikap toleransi dan kerja sama, serta menjunjung tinggi sportivitas. $^{2}$

Pada situasi pandemi, aktivitas bermain seraya belajar bisa terganggu. Berdasarkan pengakuan orang tua, anak rindu bertemu dan bermain dengan teman-teman di sekolah. Penelitian yang dilakukan Sari menemukan selama beraktivitas di rumah $41 \%$ ibu setuju bahwa anakanak menjadi rewel karena bosan dan rindu dengan lingkungan sekolahnya. ${ }^{3}$ Informasi dari Satgas Covid-19 pada bulan November 2020 menunjukkan $47 \%$ anak Indonesia merasa bosan di rumah. ${ }^{4}$ Keadaan ini membuat orang tua dan pendidik diharapkan mampu memfasilitasi pembelajaran melalui kegiatan bermain kreatif dan inovatif.

Hasil wawancara pada orang tua secara acak di Rumah Belajar All Kids menyatakan bahwa selama masa pandemi lebih memilih permainan

1 Wiwik Pratiwi. Konsep Bermain Pada Anak Usia Dini. TADBIR : Jurnal Manajemen Pendidikan Islam. 2017

2 E. Mulyasa. Manajemen PAUD. Bandung: PT Remaja Rosdakarya. 2014

3 Diah Andika Sari. Kesiapan Ibu Bermain Bersama Anak Selama Pandemi Covid 19, "Dirumah Saja". Jurnal Obsesi: Jurnal Pendidikan Anak Usia Dini.doi: 10.31004/obsesi.v5i1.584. 2020

4 Badan Nasional Penanggulangan Bencana. Informasi terbaru seputar penanganan COVID-19 di Indonesia oleh Pemerintah, https://covid19.go.id/, 2020. (accessed: 22 Desember 2020) 
indoor untuk anak dengan alasan keamanan dan kesehatan. Hasil wawancara dengan guru Rumah Belajar All Kids menemukan adanya kesulitan dalam menemukan ide bermain yang membuat anak betah di rumah. Hal ini menunjukkan baik guru maupun orang tua masih mencoba beradaptasi dalam pembelajaran daring.

Hasil observasi awal Rumah Belajar All Kids melaksanakan pembelajaran luring berjadwal dan terbatas. Peserta didik yang masuk harus dengan persetujuan orang tua. Orang tua yang belum mengijinkan anaknya masuk, tetap mendapat pelayanan terjadwal berupa home visit dan pembelajaran daring. Home visit dilakukan satu kali dalam seminggu dan pertemuan daring melalui aplikasi zoom dilakukan satu sampai dua kali dalam seminggu. Pembelajaran luring yang berlangsung dilakukan dengan tetap mematuhi protokol kesehatan.

Peserta didik di Rumah Belajar All Kids memiliki usia berbeda satu dengan yang lain. Satu ruang kelas terdiri dari anak usia 2-6 tahun. Berdasarkan teori pendekatan kurikulum Montessori oleh Bennetts dan Bone menyatakan, sebuah ruang kelas terdiri dari masyarakat mini campuran atas minat yang sama. Montessori percaya bahwa, anak akan mengasosiasikan dirinya dengan orang lain setelah berusia 6 tahun untuk kepentingan perusahaan dan juga untuk organisasi sosial: "Dia suka bergaul dengan orang lain dalam kelompok yang masing-masing memiliki status yang berbeda". ${ }^{5}$ Pendekatan ini menggabungkan anak beragam usia dalam pembelajarannya yang memberikan dampak positif terhadap perkembangan sosisal emosional dan karakter anak. Karakter yang dikembangkan di Rumah Belajar All Kids salah satunya adalah sportivitas melalui permainan.

Sportivitas di Rumah Belajar All Kids dikembangkan dengan terbiasa bermain dengan beragam usia. Guru Rumah Belajar All Kids

${ }^{5}$ Karen Bennetts dan Jane Bone. Journal of Montessori Research. American Montessori Society. Vol. 6 No. 2. 2020 
Vivi Sufiati, Dwinda Damayanti, Mengembangkan Sportivitas Melalui Permainan Modifikasi Hot (Hoki Tiup)

menyebutkan bahwa sportivitas menjadi sikap yang perlu dikembangkan untuk persiapan sekolah dasar. Menurut Beller dan Stoll sportivitas merupakan perilaku yang menunjukkan sikap hormat terhadap orang lain, berperilaku adil atas sesuatu hal, dan sikap mampu menerima hasil dari suatu pertandingan sesuai hasil akhir. ${ }^{6}$

Hasil wawancara dengan guru Rumah Belajar All Kids bahwa pengembangan sportivitas lebih sulit dikembangkan pada masa pandemi. Hal ini dikarenakan yang sebelumnya sportivitas dikembangkan dengan bermain secara bersama-sama, sementara saat ini dibatasi. Dari jumlah anak yang datang pada saat pembelajaran luring hanya berkisar 4-5. Permainan harus mematuhi protokol kesehatan yaitu memakai masker, mencuci tangan, menjaga jarak, menghindari kerumunan, dan membatasi mobilitas. ${ }^{7}$ Situasi ini membuat guru harus mempersiapkan pembelajaran sambil bermain yang memenuhi syarat diatas untuk mengembangkan sportivitas anak. Pada kegiatan bermain membutuhkan rancangan permainan yang dilengkapi dengan fasilitas berupa alat main. Hal ini sesuai dengan penelitian yang dilakukan Arifin pada anak sekolah dasar yang hasilnya menunjukkan bahwa tersedianya fasilitas dan alat pembelajaran pendidikan jasmani di sekolah menjadi faktor pendorong keberhasilan penanaman nilai sportivitas. ${ }^{8}$

Menurut Lutan, modifikasi merupakan perubahan dari keadaan lama yang sudah ada menjadi keadaan baru tanpa sepenuhnya menghilangkan karakteristik aslinya dan modifikasi ini berupa perubahan bentuk, fungsi, cara penggunaan, dan manfaat. ${ }^{9}$ Hal ini didukung dengan

6 Jennifer M. Beller dan Sharon K. Stoll. Sportsmanship: An Antiquated Concept?. Journal of Physical Education, Recreation \& Dance. doi: 10.1080/07303084.1993.10610009. 1993

7 Erza Ayu Sulistyorini. Penerapan Disiplin Protokol Kesehatan Di Era New Normal Pandemi Covid-19 Pada Anak Usia Dini di RA Muslimat Nu 15 Malang. Dewantara: Jurnal IImiah Pendidikan Islam Anak Usia Dini. 2021

${ }^{8}$ Syamsul Arifin. Internalisasi Nilai Sportivitas Melalui Pembelajaran Pendidikan Jasmani Di Sekolah Dasar. Jurnal Sosioreligi. 2017

9 Lutan Rusli. Strategi Pembelajaran Pendidikan Jasmani Dan Kesehatan. BP2MG Penjas Seterata D-II, Universitas Terbuka Jakarta. 1997 
pernyataan Ngasmain dan Soepartono bahwa permainan modifikasi merupakan perubahan teknik bermain yang menjadi lebih sederhana dari segi teknik awal yang baku.10 Perubahan di sesuaikan dengan capaian tahap tumbuh kembang anak. Modifikasi permainan untuk anak usia dini merupakan bentuk penyampaian materi permainan dengan alat dan peraturan yang lebih sederhana. Modifikasi disesuaikan dengan kebutuhan dan kemampuan serta bertujuan mempermudah dalam menyampaikan materi.

Guru Rumah Belajar All Kids melakukan modifikasi pada permainan hoki. Hoki adalah salah satu permainan yang sudah dimodifikasi menjadi hoki magnetik yang bisa ditemui di mall. Hasil modifikasi membuat permainan tidak membutuhkan lapangan luas. Menurut Taufiq dan Hartiwan pengenalan dan penerapan olahraga hoki di Indonesia masih terbilang kurang maksimal dikarenakan olahraga tersebut belum memasyarakat. ${ }^{11}$ Beradaptasi dengan situasi pandemi dan perkembangan anak usia dini, mendorong terciptanya permainan modifikasi yaitu HOT (Hoki Tiup) oleh guru Rumah Belajar All Kids. Permainan ini dikenalkan guru melalui video Youtube.

Rumah Belajar All Kids merupakan lembaga satu-satunya yang mengembangkan permainan modifikasi HOT (Hoki Tiup) untuk menstimulasi sportivitas anak. Hal ini membuat peneliti ingin mengetahui gambaran sportivitas anak melalui HOT (Hoki Tiup). Tujuan penlitian ini mendeskripsikan perencanaan permaianan HOT (Hoki Tiup), pelaksanaan permainan HOT (Hoki Tiup), dan hasil pengembangan sportivitas melalui permainan tersebut.

\footnotetext{
10 Ngasmain dan Soepartono. Modifikasi Olahraga dan Model Pembelajarannya sebagai Strategi Pembinaan Olahraga Usia Dini Bernuansa Pendidikan. Bandung 22-23 September. 1997: 3

11 Muhammad Taufiq dan Uen Hartiwan. Menigkatkan Pembelajaran Hockey Melalui Permainan 4 Gawang Kecil. Journal of Physical Education, Sport, Health and Recreation. 2014
} 


\section{METODE PENELITIAN}

Penelitian ini di lakukan pada semseter gasal tahun ajaran 2020/2021 di Rumah Belajar All Kids yang tepatnya berada di Jalan Serayu - Perumahan Mutiara Kencana B7, Kota Madiun. Penelitian ini merupakan penelitian kualitatif dengan pendekatan studi kasus. Pada penelitian ini kasus yang dianalisis adalah pengembangan sportivitas anak melalui permainan HOT (Hoki Tiup). Rumah belajar All Kids terdiri dari 14 anak dengan usia 2-6 tahun. Teknik purposive sampling digunakan untuk menentukan subjek penelitian. Subjek penelitian yang dipilih adalah anak usia 5-6 tahun yang mulai dikenalkan games. Terdapat 4 anak berusia 5-6 tahun di Rumah belajar All Kids. Pengumpulan data dilakukan dengan observasi, wawancara, dan studi dokumen. Observasi yang dilakukan adalah observasi non partisipan, dimana peneliti hanya sebagai pengamat. Wawancara mendalam dilakukan kepada guru untuk mengetahui implementasi permainan HOT (Hoki Tiup) untuk stimulasi sportivitas anak. Studi dokumen dilakukan dengan menganalisis dokumen penilaian guru tentang sportivitas anak melalui permainan HOT (Hoki Tiup).

Triangulasi teknik dilakukan dengan observasi, wawancara, dan dokumentasi untuk memperoleh hasil penelitian tentang permainan HOT (Hoki Tiup) untuk sportivitas anak. Analisis data menggunakan tahap reduksi data, penyajian data dan penarikan kesimpulan. Reduksi data merupakan proses pemilihan, pemusatan perhatian pada penyederhanaan, pengabstrakan dan transformasi data kasar yang muncul dari hasil catatan tertulis di lapangan. Penyajian data adalah menyusun kumpulan-kumpulan informasi, sehingga memungkinkan untuk dilakukan penarikan kesimpulan dan pengambilan tindakan. Ketika kembali ke lapangan dilakukan penarikan kesimpulan atas data dan informasi yang telah terkumpul. 


\section{KERANGKA TEORI}

\section{Permainan modifikasi}

Ngasmain dan Soepartono menyatakan bahwa permainan modifikasi merupakan perubahan teknik bermain yang menjadi sederhana dari segi teknik awal yang baku. ${ }^{12}$ Perubahan di sesuaikan dengan capaian tahap tumbuh kembang dan kebutuhan anak yang bertujuan mempermudah dalam menyampaikan materi. Memodifikasi dilakukan untuk membuat aktivitas menjadi lebih mudah atau lebih sulit agar sesuai tingkat capaian anak. ${ }^{13}$ Terutama pada masa pandemi. Modifikasi permainan dapat dikatakan penting untuk mendukung aktivitas belajar dan bermain anak di rumah.

Lucas menyatakan bahwa melalui aktivitas bermain, seorang anak akan mengenal dunia di sekitarnya secara alami melalui eksperimen dan penemuan yang membangun pengalamannya sendiri, selain itu anak juga mengenal budaya yang berkontribusi pada aspek fisik, sosial, dan emosi. ${ }^{14}$ Guru mengunggah ide modifikasi permainan dalam video YouTube. Guru juga mengirimkan link permainan tersebut kapada orang tua.

\section{Sportivitas melalui bermain}

Sportivitas merupakan perilaku yang menunjukkan sikap hormat terhadap orang lain, berperilaku adil atas suatu hal atau kejadian, dan sikap mampu menerima hasil dari suatu pertandingan sesuai hasil akhir. ${ }^{15}$ Tidak semua bermain dan permainan memiliki aturan. Menurut Battelheim bermain adalah kegiatan yang tidak memiliki aturan kecuali yang

12 Ngasmain dan Soepartono. Modifikasi Olahraga dan Model Pembelajarannya sebagai Strategi Pembinaan Olahraga Usia Dini Bernuansa Pendidikan. Bandung 22-23 September. 1997: 3

${ }^{13}$ Simone Davies. The Montessori Toddler. Yogyakarta: Bentang Pustaka. 2019

${ }^{14}$ Francisco Manuel Moreno Lucas. The Game as an Early Childhood Learning Resource for Intercultural Education. Procedia - Social and Behavioral Sciences. doi: 10.1016/j.sbspro.2017.02.127. 2017

15 Jennifer M. Beller dan Sharon K. Stoll. Sportsmanship: An Antiquated Concept?. Journal of Physical Education, Recreation \& Dance. doi: 10.1080/07303084.1993.10610009. 1993 
Vivi Sufiati, Dwinda Damayanti, Mengembangkan Sportivitas Melalui Permainan Modifikasi Hot (Hoki Tiup)

ditetapkan oleh pemain itu sendiri, dan tidak ada hasil akhir yang dimaksudkan dalam realitas luar. ${ }^{16}$ Bermain dapat dikombinasikan dengan kegiatan pembelajaran agar proses belajar menjadi lebih menyenangkan. Mentaati aturan bermain akan melatih sportivitas. Anak juga dapat lebih mudah diarahkan mengenai permainan kompetisi, anak mampu menghargai teman dan lawan dalam bermain, anak berusaha bermain secara fair dalam mencapai kemenangan, dan anak dapat menerima kemenangan atau kekalahan dengan tidak merendahkan satu sama lain. Kompetensi dasar sosial emosional dapat distimulasi dengan pembiasaan lisan dan tindakan. Pembiasaan lisan dan tindakan dapat diberikan melalui kegiatan yang dilakukan dalam kehidupan. ${ }^{17}$ Sportivitas akan memberikan kemudahan dalam kehidupan anak. Selain itu juga akan membentuk karakter dan kepribadian anak, sehingga penting untuk dipahami, ditanamkan, dan dikembangkan sejak usia dini.

\section{TEMUAN DAN PEMBAHASAN}

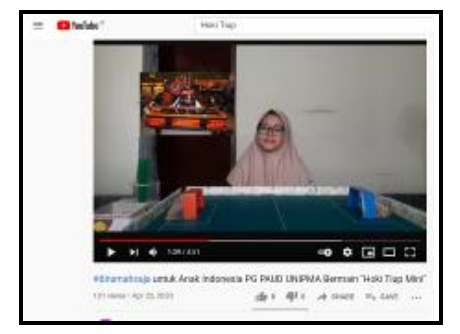

Gambar 1. Situs Youtube panduan bermain Hoki Tiup https://youtu.be/ilu0xmaKoSi

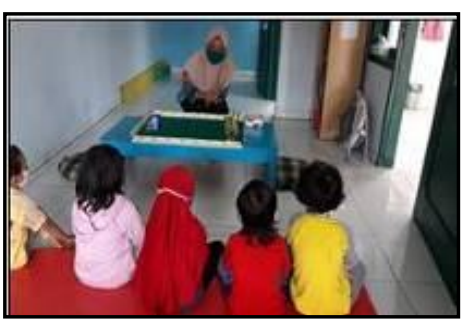

Gambar 2. Guru menjelaskan permainan Hoki Tiup

Guru Rumah Belajar All Kids membuat alat permainan HOT (Hoki Tiup) menggunakan papan bermain yang terbuat dari styrofoam berukuran $80 \mathrm{~cm}$ x $60 \mathrm{~cm}$ dengan luas sketsa lapangan $70 \mathrm{~cm} \times 50 \mathrm{~cm}$. Pada tepi papan terdapat pagar yang terbuat dari kardus untuk mencegah bola keluar papan bermain. Alat dan bahan yang digunakan dalam

\footnotetext{
${ }^{16}$ Elizabeth Hurlock. Perkembangan Anak. Jakarta: Erlangga. 1978

17 Vivi Sufiati. Pengembangan Kompetensi Dasar Sosial Emosional dalam Hidden Curriculum. pp. 2019: 241-245
} 
membuat alat permainan ini mudah didapatkan. Menurut Syahni, memanfaatkan barang-barang di lingkungan sekitar, dapat membantu guru maupun orang tua dalam membuat alat permainan yang murah dan mudah dibuat untuk memfasilitasi bermain anak. ${ }^{18}$ Kardus yang digunakan adalah kardus bekas. Nurani juga menyatakan bahwa selain membantu mengurangi sampah melalui proses menggunakan kembali (recycle) material yang sudah tidak digunakan dengan memberikan sentuhan baru, sehingga menghasilkan suatu barang yang dapat digunakan kembali. ${ }^{19}$

Menurut Creighton dan Szymkowiak, sekolah di masa depan menggunakan permainan secara efektif yang memberi pengalaman berkesan pada anak selama bermain dan tetap menawarkan solusi hemat biaya untuk meningkatkan hasil pembelajaran. ${ }^{20}$ Permainan HOT (Hoki Tiup) di Rumah Belajar All Kids memenuhi kriteria tersebut yaitu permainan yang menyenangkan dan hemat biaya pembuatan. Menyenangkan karena ada unsur kebaruan. Hemat biaya karena bahan terjangkau, mudah didapat, dan mudah dibuat.

Guru Rumah Belajar All Kids merencanakan aturan main untuk permainan HOT (Hoki Tiup). Aturan main yang dibuat mendukung pengembangan sikap sportivitas anak. Berikut aturan main dalam permainan HOT (Hoki Tiup) : (1) dimainkan oleh 2 anak, (2) 1 ronde permainan di sediakan 3 bola (tidak ada batas waktu bermain), (3) anak melakukan suit untuk menentukan siapa yang pertama menggerakkan bola, (4) anak menggiring bola dengan meniup sedotan hingga bola masuk ke dalam gawang lawan, pemain dilarang menggunakan tangan

18 Della Syahni. Daur Ulang Sampah Plastik di Idonesia Rendah, Mongabay Indonesia. 2018. Available at: https://www.mongabay.co.id/2019/09/10/daur-ulang-sampah-plastikdi-indonesia-rendah/ (Accessed: 28 Januari 2021)

${ }_{19}$ Yuliani Nurani. Pengembangan Media Daur Ulang Berbasis Kecerdasan Jamak Dalam Peningkatan Keterampilan Hidup Anak Usia Dini. Jurnal Cakrawala Pendidikan. doi: 10.21831/cp.v0i1.1467. 2013

20 Susan Creighton dan Andrea Szymkowiak. The Effects of Cooperative and Competitive Games on Classroom Interaction Frequencies. Procedia - Social and Behavioral Sciences. doi: 10.1016/j.sbspro.2014.04.402. 2014 
Vivi Sufiati, Dwinda Damayanti, Mengembangkan Sportivitas Melalui Permainan Modifikasi Hot (Hoki Tiup)

secara langsung, (5) pemain bertanggung jawab atas gawang masingmasing, (6) akhir permainan (bola habis), menghitung masing-masing bola yang telah berhasil dimasukkan, (7) anak yang mendapat bola paling sedikit mengambil lipatan kertas secara acak dalam wadah dan harus mengekspresikan gambar yang ada. Permainan ini memiliki tujuan untuk mengenalkan olahraga hoki modifikasi berskala kecil.

Di Rumah Belajar All Kids permainan HOT (Hoki Tiup) dilakukan di dalam ruangan. Modifikasi permainan hoki menjadi hoki tiup memberikan alternatif untuk menyederhanakan permainan sesuai dengan fisik dan psikologis yang dimiliki anak usia dini. Modifikasi juga dilakukan untuk adaptasi terhadap situasi pandemi dengan mengubah permainan outdoor menjadi indoor. Hal ini menunjukkan bahwa modifikasi bertujuan untuk membuat aktivitas lebih mudah atau lebih sulit sesuai level anak. ${ }^{21}$

Permainan HOT (Hoki Tiup) lengkap dengan alat main hanya terdapat satu set di Rumah Belajar All Kids. Anak harus bergantian secara berpasangan dalam memainkannya karena hanya ada 1 set alat permainan. Guru di Rumah Belajar All Kids menggunakannya untuk kegiatan pembelajaran. Penelitian Sari menunjukkan bahwa saat anak bermain bersama secara bergantian dapat memberikan manfaat dalam meningkatkan keterampilan sosial dan menjadikan suatu karakter yang mumpuni dimiliki anak. 22 Manfaat tersebut seperti, anak secara aktif melakukan komunikasi dengan temannya, anak tidak kasar dalam bersikap, mau mengantri, menghargai temannya, dan mau bekerja sama. Di Rumah Belajar All Kids, anak dibiasakan untuk bermain bersama secara bergantian dengan teman seusianya ataupun teman yang berbeda usia. Menurut Hurlock, bermain bersama akan menciptakan sebuah interaksi berupa hubungan sosial dan memecahkan masalah yang timbul

${ }^{21}$ Simone Davies. The Montessori Toddler. Yogyakarta: Bentang Pustaka. 2019

22 Diah Andika Sari. Meningkatkan Perilaku Prososial Anak Usia 4-5 Tahun Melalui Metode Eksperimental dengan Permainan Tradisional. Yaa Bunayya: Jurnal Pendidikan Anak Usia Dini. 2018 
dalam hubungan masyarakat. ${ }^{23} \mathrm{Hal}$ ini akan memberikan manfaat pada diri anak, yaitu menjadi lebih pandai, kreatif, mampu bekerjasama, memiliki tenggang rasa, dan memiliki kemampuan sosial yang baik.

Di Rumah Belajar All Kids anak antusias memainkan permainan Hoki Tiup. Hal ini terbukti dari anak yang memainkan permainan dengan inisiatif sendiri. Mutiah menyatakan bahwa semua jenis permainan memiliki tujuan yang sama yaitu dapat dimainkan dan menghasilkan rasa menyenangkan saat permainan berlangsung ataupun setelah permainan selesai. ${ }^{24}$ Senada dengan Hadfield yang menyatakan game sebagai aktivitas dengan aturan, tujuan, dan unsur yang menyenangkan. ${ }^{25}$

Permainan HOT (Hoki Tiup) dimainkan dengan cara menggiring bola dengan ditiup dan dalam memainkannya dilakukan secara berlawanan sehingga memunculkan suasana kompetisi. Kompetisi yang menyenangkan akan menstimulasi sportivitas anak. Guru di Rumah Belajar All Kids menyatakan bahwa sportivitas dimiliki anak dengan melakukan usaha dalam sebuah permainan kompetisi sehingga memiliki hati yang mampu menerima kekalahan ataupun kemenangan (fair play). Hal ini sesuai dengan hasil penelitian bahwa permainan tradisional dapat menjadi sarana untuk mengembangkan dan melatih anak untuk bersosialisai, dapat bekerja sama dengan baik dengan teman, memiliki sikap empati terhadap sesama, melatih siswa untuk bertanggung jawab terhadap tugas yang diberikan, dan melatih persaingan sehat, jujur dan sportif didalamnya. ${ }^{26}$ Permainan modifikasi HOT (Hoki Tiup) dan permainan tradisional memiliki persamaan dalam hal aturan dan kompetisi anak untuk mengembangkan persaingan sehat, jujur dan sportif.

\footnotetext{
${ }^{23}$ Muhammad Fadillah. Desain Pembelajaran PAUD. Yogyakarta. AR-RUZZ Media. 2016 24 Diana Mutiah. Psikologi Bermain Anak Usia Dini. Jakarta: Kencana Prenada Media. 2012

25 Jill Hadfield. Elementary Communication Games. Longman: Addison Wesley Longman Ltd. 1996: 5

${ }^{26}$ M. Hery Yuli Setiawan. Melatih Keterampilan Sosial Anak Usia Dini Melalui Permainan Tradisional. Jurnal Dimensi Pendidikan Dan Pembelajaran. 2016
} 
Vivi Sufiati, Dwinda Damayanti, Mengembangkan Sportivitas Melalui Permainan Modifikasi Hot (Hoki Tiup)

Guru menanamkan sportivitas pada diri anak melalui pembiasaan dan permainan dalam kegiatan bermain sehari-hari. Sportivitas merupakan bagian dari kompetensi sosial emosi anak. Menurut Sufiati, kompetensi dasar sosial emosional dapat distimulasi dengan pembiasaan lisan dan tindakan. ${ }^{27}$ Bentuk pembiasaan lisan untuk sportivitas adalah mengucapkan selamat untuk yang menang dan menghibur yang kalah. Pembisaan lisan yang menunjukkan sportivitas ini belum nampak pada subjek penelitian. Bentuk pembiasaan tindakan untuk sikap sportivitas adalah dengan tindakan menaati peraturan main. Pembiasaan tindakan ini terlihat dalam permainan HOT (Hoki Tiup). Semua anak menaati peraturan, meskipun masih ada yang perlu diingatkan.

Cara Rumah Belajar All Kids menanamkan sportivitas pada diri anak adalah dengan memberikan contoh. Bandura menyatakan bahwa mengamati tingkah laku orang lain merupakan salah satu cara cepat untuk mempelajari situasi sosial. ${ }^{28}$ Guru memberi contoh nyata pembiasaan sportif melalui pembiasaan mentaati aturan main dan menerima hasil main. Cara tersebut mampu menumbuhkan sportivitas dalam diri anak. Anak masih membutuhkan arahan untuk menaati peraturan. Anak perlu diingatkan untuk menaati aturan.

Guru mengajarkan permainan hoki tiup melalui tahapan-tahapan. Menurut Mulyanti tahapan games (permainan) adalah menyiapkan perencanaan harian dan pijakan lingkungan, melakukan demonstrasi, bercakap-cakap dan melakukan kegiatan permainan. ${ }^{29}$ Menyiapkan perencanaan harian, permainan modifikasi HOT (Hoki Tiup) dikenalkan pada seluruh anak yang hadir, namun lebih difokuskan pada anak yang

27 Vivi Sufiati. Pengembangan Kompetensi Dasar Sosial Emosional dalam Hidden Curriculum. pp. 2019: 241-245

28 William Crain. Teori Perkembangan Konsep dan Aplikasi. Yogyakarta: Pustaka Pelajar. 2007

29 Mulyanti, Agus., Aunurrahman, dan Sri Lestari. Analisis Penerapan Metode Games (Permainan) Dalam Meningkatkan Kemampuan Berbahasa Anak Usia 4-5 Tahun. Jurnal Pendidikan dan Pembelajaran Khatulistiwa, 2, pp. 2013: 1-15 
berusia 5-6 tahun. Di Rumah Belajar All Kids, ketika melakukan sebuah kegiatan kompetisi, guru selalu mengingatkan bahwa menang atau kalah merupakan hal yang biasa dalam suatu permainan. Guru selalu memberikan arahan untuk saling menghargai jika ada teman yang kalah atau belum bisa. Pijakan lingkungan dilakukan sebelum anak bermain, yaitu guru menyiapkan alat permainan yang akan digunakan dan mengkondisikan keadaan untuk mendukung terciptanya ruang bermain yang kondusif.

Permainan dilakukan pagi hari sebelum kegiatan inti. Hal ini dilakukan karena keadaan anak yang masih bersemangat dan bertenaga, sehingga anak memiliki antusias dalam kegiatan bermain. Anak diarahkan untuk duduk di matras berhadapan langsung dengan meja yang diatasnya terdapat alat permaianan HOT (Hoki Tiup). Anak terlihat penasaran dan guru memberikan penjelasan melalui demonstrasi terkait nama permainan, alat-alat yang digunakan, dan cara bermain. Anak terlihat tenang dan fokus dalam memahami penjelasan tanpa ada kegaduhan. Guru dan anak juga melakukan cakap-cakap terkait permainan Hoki Tiup.

Tabel 1 Temuan Sportivitas Anak

\begin{tabular}{|c|c|c|c|}
\hline \multirow{3}{*}{$\begin{array}{c}\text { Nama } \\
\text { Anak } \\
M\end{array}$} & \multicolumn{3}{|c|}{ Sportivitas } \\
\hline & Menghormati & Adil & Menerima Hasil \\
\hline & $\begin{array}{l}\text { Ketika menang hanya } \\
\text { senyum tanpa berkata- } \\
\text { kata. }\end{array}$ & $\begin{array}{l}\text { Tidak curang. } \\
\text { Bermain dengan siapa } \\
\text { saja. } \\
\text { Bersedia bergantian dan } \\
\text { antri main. }\end{array}$ & $\begin{array}{l}\text { Bersedia menerima } \\
\text { konsekuensi } \\
\text { kekalahan dengan } \\
\text { pasrah/lemas. }\end{array}$ \\
\hline$R$ & $\begin{array}{lr}\text { Ketika } & \text { menang } \\
\text { bersorak } & \text { tanpa } \\
\text { menyakiti teman. } & \\
\text { Mendengarkan } & \text { ketika } \\
\text { diingatkan } & \text { tentang } \\
\text { aturan main. } & \end{array}$ & $\begin{array}{l}\text { Tidak curang } \\
\text { Bersedia bermain dengan } \\
\text { siapapun. } \\
\text { Perlu diingatkan aturan } \\
\text { main. }\end{array}$ & $\begin{array}{l}\text { Bersedia menerima } \\
\text { konsekuensi } \\
\text { kekalahan dengan } \\
\text { ekspresi datar. }\end{array}$ \\
\hline $\mathrm{C}$ & $\begin{array}{l}\text { Mematuhi aturan main } \\
\text { sesuai dengan } \\
\text { kesepakatan. } \\
\text { Menolak ajakan main } \\
\text { dengan sopan. }\end{array}$ & $\begin{array}{l}\text { Bersedia main bergantian } \\
\text { dan antri. } \\
\text { Mengikuti aturan main. } \\
\text { Menghindari teman yang } \\
\text { mengalahkan. }\end{array}$ & $\begin{array}{lr}\text { Setelah } & \text { kalah } \\
\text { menerima } & \\
\text { konsekuensi } & \text { dan } \\
\text { memilih } & \text { ganti } \\
\text { permainan. } & \end{array}$ \\
\hline I & $\begin{array}{lr}\text { Ketika } & \text { menang } \\
\text { bersorak, } & \text { berlari } \\
\text { mengelilingi } & \text { ruang. }\end{array}$ & $\begin{array}{l}\text { Bersedia bermain dengan } \\
\text { siapapun. } \\
\text { Bersedia main bergantian } \\
\text { dan antri. }\end{array}$ & $\begin{array}{lr}\text { Bersedia } & \text { menerima } \\
\text { konsekuensi } & \text { menang } \\
\text { kalah } & \text { dengan } \\
\text { senyum. } & \\
\text { senyal }\end{array}$ \\
\hline
\end{tabular}


\begin{tabular}{|l|l|l|l|}
\hline & & $\begin{array}{l}\text { Perlu dingatkan aturan } \\
\text { main. }\end{array}$ & \\
\hline
\end{tabular}

$\mathrm{R}$ antusias dalam bermain. $\mathrm{R}$ memahami cara dan aturan bermain secara cepat. $R$ bersemangat dan gesit dalam bermain dibanding pasangan mainnya. Setiap anak memiliki kemampuan berbeda, ada yang mampu cepat belajar dan ada pula yang lambat. Seperti yang dikemukakan Marzollo dan Lloyd (dalam Tejasaputra, 2001) bahwa anak dapat meningkatkan kemampuan dirinya melalui kegiatan bermain, namun tidak semua anak memiliki kemampuan yang sama dalam bermain. ${ }^{30} \mathrm{Hal}$ ini juga dapat dipengaruhi dari kesesuaian usia anak dan lingkungan dalam kesehariannya.

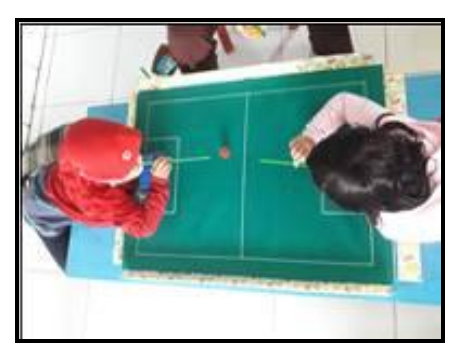

Gambar 3. Anak bermain Hoki Tiup

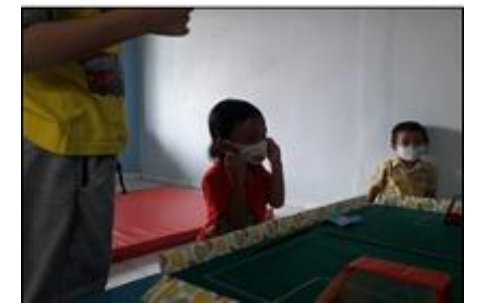

Gambar 4. Anak menerima konsekuensi menirukan ekspresi gambar

Dari hasil akhir permaianan terlihat bahwa $R$ mampu menghormati dan bersikap adil, selain itu juga mampu menerima hasil atas permainan yang dimainkan. Sikap hormat dan menerima hasil terlihat melalui bagaimana cara $R$ mengeksperikan kemenangannya yaitu dengan menunjukkan ekspresi gembira dan sempat berlari dengan sorakan hore tanpa mengucapkan kata-kata yang dapat menyakiti hati temannya yang kalah. $\mathrm{R}$ tidak selalu menang saat bermain. Ketika kalah, $\mathrm{R}$ mau menerima konsekuensi meski dengan wajah datar. $\mathrm{R}$ memiliki sikap adil dengan semua teman dengan bersedia main dengan semua teman. $R$ juga bermain bersama teman-teman lain yang lebih muda dari usianya tanpa membeda-bedakan.

${ }^{30}$ Mayke S. Tedjasaputra. Bermain, Mainan dan Permainan. Jakarta: Grasindo. 2001 
$M$ kurang memahami aturan main. $M$ mampu menghormati dan bersikap adil, serta menerima hasil permainan. $M$ tidak marah ataupun mengucapkan kata-kata negative ketika mengalami kekalahan. $M$ menerima kekalahan dengan pasrah. $\mathrm{M}$ mengambil lipatan kertas sebagai konsekuensi atas kekalahannya serta memperagakannya gambar dari kertas. $M$ memperlihatkan senyum bahagia ketika menang. $M$ bersikap adil dengan bermain bersama teman-teman lain yang lebih muda dari usianya. $\mathrm{M}$ juga berusaha mengikuti aturan main meski tidak jarang ada yang lupa.

I memiliki semangat kompetisi, namun tetap menghormati temannya yang kalah tanpa melontarkan ejekan ataupun kata-kata yang menyakiti hati teman. I mampu memahami dan mengikuti aturan bermain. I memperlihatkan senyum bahagia, sorakan hore dan berputar dalam ruangan ketika menjadi pemenang. I bersedia melakukan konsekuensi ketika kalah. I selalu berusaha mencoba lagi dan lagi ketika kalah. I sangat antusias bermain permainan HOT (Hoki Tiup) ini. Ketika jam pulang dan menunggu jemputan, I mengajak teman lain untuk bermain bersama.

C bermain dengan santai. C mematuhi aturan main yaitu menggerakan bola dengan cara meniup. $C$ tidak menggunakan tangan secara langsung untuk menggerakan bola. Ketika mengalami kekalahan, C mau menerima konsekuensi atas hasil akhir permainan. C mampu menghormati teman dan bermain dengan tidak marah atau mengucapkan kata-kata yang dapat menyakiti hati saat mengalami kekalahan. $\mathrm{C}$ lebih memilih bermain mainan lain karena selalu mengalami kekalahan jika menghadapi lawan yang sama. C menolak bermain dengan kata-kata sopan. Namun, $C$ tidak berhenti mencoba bermain, dihari-hari berikutnya $\mathrm{C}$ bermain permainan modifikasi ini dengan teman lainnya. 
Vivi Sufiati, Dwinda Damayanti, Mengembangkan Sportivitas Melalui Permainan Modifikasi Hot (Hoki Tiup)

Permainan HOT (Hoki Tiup) menstimulasi sportivitas dalam kompetisi bermain. Anak menghormati teman dalam situasi sedang bermain, situasi menang, dan kalah. Anak yang mengalami kekalahan bisa tertantang mencoba lagi. Anak yang menang semakin semangat bermain. Anak tidak berhenti ketika telah mendapatkan kemenangan, anak tetap mengulangi bermain untuk mengasah kemampuannya. Anak mengikuti peraturan main dan bersedia bermain dengan semua teman, serta antri atau main bergantian. Hasil penelitian ini sesuai dengan penelitian di SD tentang pengaruh minat bermain lompat tali terhadap sikap sportivitas siswa sebesar 45,2 \%. Hal ini terlihat dari sikap dewasa setiap anak dalam berlomba-lomba meningkatkan prestasi kelas, kompak pada saat mengerjakan tugas yang bersifat tugas kelompok, menerima setiap hasil belajar dengan baik tanpa menyalahkan orang lain, berjiwa besar pada saat usaha yang dilakukan tidak sesuai dengan harapan. ${ }^{31}$ Perbedaan dengan penelitian ini adalah jenis permainan dan subjek penelitian.

Melalui bermain HOT (Hoki Tiup) anak belajar bekerjasama, tanggung jawab pada diri sendiri, dan memahami etika bersaing. Sheridan dan Williams menyatakan bahwa dari sudut pandang pedagogis, prasekolah adalah sebuah lingkungan belajar di mana anak-anak dapat belajar dan bertindak secara individu, serta bekerjasama dan bersaing secara konstruktif. ${ }^{32}$ Penelitian lain yang sesuai adalah penelitian tentang pendidikan jasmani olahraga dan kesehatan yang memberikan pembiasaan berperilaku sportif sehingga membiasakan individu memilki jiwa yang berkarakter. ${ }^{33}$ Pada anak usia dini pendidikan jasmani olahraga

31 Slamat Fitriyadi. Pengaruh Permainan Tradisional Lompat Tali Terhadap Sikap Sportivitas Siswa Sekolah Dasar (SD). Journal Of Educational Review And Research. 2020

32 Sonja Sheridan dan Pia Williams. Constructive Competition In Preschool. Journal of Early Childhood Research. doi: 10.1177/1476718X06067581. 2006

33 Dhedhy Yuliawan. Pembentukan Karakter Anak Dengan Jiwa Sportif Melalui Pendidikan Jasmani Olahraga dan Kesehatan. Jurnal Sportif. 2016 
diberikan melalui permainan, pada penelitian ini adalah permainan HOT (Hoki Tiup).

Tedjasaputra menyatakan bahwa anak usia prasekolah dapat mengenal konsep sambil bermain, anak akan merasa senang dan tanpa disadari ternyata telah belajar banyak hal. ${ }^{34}$ Ketika bermain permainan modifikasi Hoki Tiup, anak belajar menanggapi hasil pemainan. Anak belajar ketika mendapat kemenangan yaitu akan merasa senang dan menampilkan ekspresi wajah gembira, tanpa disadari anak telah belajar cara mengekspresikan diri, cara bermain mencapai kemenangan dan bersikap sportif ketika melihat teman kalah. Anak yang kalah secara otomatis mendapatkan konsekuensi. Ketika mendapatkan konsekuensi, anak harus menirukan gambar yang tanpa di sadari anak belajar bersikap sportif dan mengembangkan pengetahuan atas ekspresi emoticon atau ciri-ciri gambar hewan yang didapatnya.

\section{KESIMPULAN}

Permainan HOT (Hoki Tiup) di Rumah Belajar All Kids digunakan untuk menstimulasi sportivitas anak. Kegiatan ini dimulai dari guru membuat perencanaan permainan beserta alat main. Guru membuat alat permainan HOT (Hoki Tiup) dengan peralatan yang mudah ditemukan dan aman untuk anak. Guru mengajarkan permainan dengan memberikan contoh. Anak selanjutnya bermain dengan dampingan guru.

Permainan ini terbukti menstimulasi sportivitas anak yang ditandai dengan berkembangnya karakter adil, menghormati, dan menerima. Sikap adil ditandai dengan anak mulai menaati aturan main ketika bermain dengan semua teman. Sikap menghormati ditunjukkan melalui ekspresi wajar ketika mengalami kemenangan maupun kekalahan. Hasil akhir dari permainan tidak menimbulkan permusuhan sesama teman karena anak mulai belajar menerima hasil permainan.

${ }^{34}$ Mayke S. Tedjasaputra. Bermain, Mainan dan Permainan. Jakarta: Grasindo. 2001 
Pengembangan sportivitas selanjutnya dapat distimulasi lagi dengan memberi contoh anak untuk menghibur teman yang kalah dan terus mencoba jika mengalami kekalahan. Guru bisa mengembangkan permainan lain yang lebih bervariasi untuk menstimulasi sportivitas anak.

\section{DAFTAR PUSTAKA}

Arifin, Syamsul. 2017. Internalisasi Nilai Sportivitas Melalui Pembelajaran Pendidikan Jasmani Di Sekolah Dasar. Jurnal Sosioreligi. 15(2).

Badan Nasional Penanggulangan Bencana. 2020. Informasi terbaru seputar penanganan COVID-19 di Indonesia oleh Pemerintah, https://covid19.go.id/, (Accessed: 22 Desember 2020).

Beller, Jennifer M. dan Stoll, Sharon K. 1993. Sportsmanship: An Antiquated Concept?. Journal of Physical Education, Recreation \& Dance. doi: 10.1080/07303084.1993.10610009.

Bennetts, Karen dan Bone, Jane. 2020. Journal of Montessori Research. American Montessori Society. 6(2).

Crain, William. 2007. Teori Perkembangan Konsep dan Aplikasi. Yogyakarta: Pustaka Pelajar.

Creighton, Susan dan Szymkowiak, Andrea. 2014. The Effects of Cooperative and Competitive Games on Classroom Interaction Frequencies. Procedia - Social and Behavioral Sciences. doi: 10.1016/j.sbspro.2014.04.402.

Davies, Simone. 2019. The Montessori Toddler. Yogyakarta: Bentang Pustaka.

Fadillah, Muhammad. 2016. Desain Pembelajaran PAUD. Yogyakarta. AR-RUZZ Media.

Fitriyadi, Slamat. 2020. Pengaruh Permainan Tradisional Lompat Tali Terhadap Sikap Sportivitas Siswa Sekolah Dasar (SD). Journal Of Educational Review And Research. 3(2). p 71 - 79.

Hadfield, Jill. 1996. Elementary Communication Games. Longman: Addison Wesley Longman Ltd.

Hurlock, Elizabeth. 1978. Perkembangan Anak. Jakarta: Erlangga.

Lucas, Francisco Manuel Moreno. 2017. The Game as an Early Childhood Learning Resource for Intercultural Education. Procedia - Social and Behavioral Sciences. doi: 10.1016/j.sbspro.2017.02.127. 
Lutan, Rusli. 1997. Strategi Pembelajaran Pendidikan Jasmani Dan Kesehatan. BP2MG Penjas Seterata D-II, Universitas Terbuka Jakarta.

Mulyanti, Agus., Aunurrahman, dan Sri Lestari. 2013. Analisis Penerapan Metode Games (Permainan) Dalam Meningkatkan Kemampuan Berbahasa Anak Usia 4-5 Tahun. Jurnal Pendidikan dan Pembelajaran Khatulistiwa, 2, pp. 1-15.

Mulyasa, E. 2014. Manajemen PAUD. Bandung: PT Remaja Rosdakarya.

Mutiah, Diana. 2012. Psikologi Bermain Anak Usia Dini. Jakarta: Kencana Prenada Media.

Ngasmain dan Soepartono. 1997. Modifikasi Olahraga dan Model Pembelajarannya sebagai Strategi Pembinaan Olahraga Usia Dini Bernuansa Pendidikan. Bandung 22-23 September.

Nurani, Yuliani. 2013. Pengembangan Media Daur Ulang Berbasis Kecerdasan Jamak Dalam Peningkatan Keterampilan Hidup Anak Usia Dini. Jurnal Cakrawala Pendidikan.

doi:10.21831/cp.v0i1.1467.

Pratiwi, Wiwik. 2017. Konsep Bermain Pada Anak Usia Dini. TADBIR : Jurnal Manajemen Pendidikan Islam. 5(2).

Sari, Diah Andika. 2018. Meningkatkan Perilaku Prososial Anak Usia 4-5 Tahun Melalui Metode Eksperiental Dengan Permainan Tradisional. Yaa Bunayya: Jurnal Pendidikan Anak Usia Dini.

Sari, Diah Andika. 2020. Kesiapan Ibu Bermain Bersama Anak Selama Pandemi Covid-19, "Dirumah Saja". Jurnal Obsesi: Jurnal Pendidikan Anak Usia Dini. doi: 10.31004/obsesi.v5i1.584.

Setiawan, M. Hery Yuli. 2020. Melatih Keterampilan Sosial Anak Usia Dini Melalui Permainan Tradisional. Jurnal Dimensi Pendidikan Dan Pembelajaran.

Sheridan, Sonja dan Williams, Pia. 2006. Constructive Competition In Preschool. Journal of Early Childhood Research. doi: 10.1177/1476718X06067581.

Sufiati, Vivi. 2019. Pengembangan Kompetensi Dasar Sosial Emosional dalam Hidden Curriculum. pp. 241-245.

Sulistyorini, Erza Ayu. 2021. Penerapan Disiplin Protokol Kesehatan Di Era New Normal Pandemi Covid-19 Pada Anak Usia Dini di RA Muslimat Nu 15 Malang. Dewantara: Jurnal IImiah Pendidikan Islam Anak Usia Dini. 
Vivi Sufiati, Dwinda Damayanti, Mengembangkan Sportivitas Melalui Permainan Modifikasi Hot (Hoki Tiup)

Syahni, Della. 2018. Daur Ulang Sampah Plastik di Idonesia Rendah, Mongabay Indonesia. Available at: https://www.mongabay.co.id/2019/09/10/daur-ulang-sampahplastik-di-indonesia-rendah/ (Accessed: 28 January 2021).

Yuliawan, Dhedhy. 2016. Pembentukan Karakter Anak Dengan Jiwa Sportif Melalui Pendidikan Jasmani Olahraga dan Kesehatan. Jurnal Sportif. 2(1).

Taufiq, Muhammad dan Hartiwan, Uen. 2014. Menigkatkan Pembelajaran Hockey Melalui Permainan 4 Gawang Kecil. Journal of Physical Education, Sport, Health and Recreation.

Tedjasaputra, Mayke S. 2001. Bermain, Mainan dan Permainan. Jakarta: Grasindo. 